\title{
Summary of the Papers Presented at the 2014 Conference of IIAS and Published in "Atlanti" 2014
}

\author{
Charles KECSKEMÉTI, P P.D. \\ former Secretary General of ICA. \\ e-mail: k.kecskemeti@orange.fr
}

\begin{abstract}
The 2014 Conference dealt with two themes under the overall title of Archives-political powercivil society.
\end{abstract}
Tome 1: Archives - political power - civil society: Archives and human rights, Ac- cess and legal requirements (data protection, copyright)

\section{Inaugural session}

Greetings and opening addresses were delivered by Peter Pavel Klasinc, Director of IIAS, who reminded that the Institute was operating in Trieste since 10 years, Grazia Tatò, Director of the IIAS Autumn Archival School, Claudia Salmini, Director of the State Archives of Trieste, Cristina Benussi on behalf of the Dean of the University of Trieste, Laura Famulari, on behalf of the Mayor of Trieste, Franci Demšar, Director of the Slovenian Research Agency and Ludvik Toplak, President of Alma Mater Europea - The European Centre Maribor, Mauro Tosti Croce, President of the Assembly of Members of the IIAS. All speakers emphasized the importance of the two topics selected for the Conference. The representatives of the Italian and Slovenian authorities expressed their satisfaction on the work and achievements of IIAS and congratulated the European University of Maribor on the opening of post-graduate studies in archival science and documentology.

The Conference was then addressed by David Leitch, Secretary General of the ICA. He reviewed the action of ICA and of its Sections and Working groups during the elapsed year. So far no Sections had been established for Military, Foreign Ministry or Judicial Archives, but ICA intended to fill these gaps. The activities of EURBICA, ICA's European Branch, were currently being reconsidered, Whatever the outcome of these reflections, there would be a need and opportunity for IIAS to play an increased role on the European scene.

Peter Pavel KLASINC, Activities of the International Institute for Archival Science Trieste/Italy - Maribor/Slovenia from October 2013 to October 2014 (29) ${ }^{1}$

Prof. Klasinc expressed his gratitude to the staff of the State Archives of Trieste. Thanks to their support, IIAS pursued its regular activities (International Archives Day, Atlanti 24 and Autumn Archives School) during the elapsed year. Contacts were maintained with 24 countries.

Charles KECSKEMETI, presented then the Summary of the papers published in "Atlanti" 23(2013) (23).

\section{General introduction}

Peter Pavel KLASINC, Archives Between the Profession, Policy and Civil Society (45)

In introducing the first theme of the Conference, Prof. Klasinc surveyed successively: i) the involvement of the profession in politics, especially through the preparation of archival legislation; ii) the controlling of the implementation of the archives law by the Ombudsman; iii) possible conflicts between politics and the Code of Ethics; iv) the objectives of the Universal Declaration of Archives and v) the European rules for the protection of personal data, the use of archives for the protection of Human Rights and the role of the European Archival Group.

1. Within brackets: the page where the paper begins. 


\section{Archives and human rights}

Michael COOK, The International Human Rights Movement: How Should Archivists Respond $(61)^{2^{*}}$

Archives are directly concerned by the international instruments relating to Human Rights (Universal Declaration of Human Rights, Council of Europe Convention on Data Protection, Treaty of Lisbon etc.), as well as by the texts adopted for Truth and Reconciliation in countries, which experienced repressive regimes in the $20^{\text {th }}$ century. ICA's Human Rights Working Group, chaired by Trudy Peterson, is monitoring since July 2010, through its monthly newsletter, international and national actions and events concerning human rights that have relevance for the archival profession and institutions.

Giulia BARRERA, The Draft EU Data Protection Regulation and its Impact on Archives ${ }^{3 * *}$

In January 2012, the European Commission adopted the text of the Regulation to be approved by the European Parliament and the Council of the EU. Draft amendments passed in October 2013 call for the destruction or anonymization of records containing personal data no longer necessary "for the purposes for which the personal data are processed". Since these amendments are incompatible with the interest of scholarly research as well as with the archival legislation of most European countries, rectification has been requested by an on line Petition (50 000 signatures) and by the European Archival Group. Discussions continue in the European Parliament.

Snežana PEJOVIĆ, Interest of Political Elites of Societies in Transition in Historical Archives: Experiences from Montenegro (67)

The attitude of the political elites of Montenegro towards archives and cultural heritage is marked by several negative factors such as underdevelopment of the country, lack of democratic culture and the politicization of the archival profession due its incorporation in the state machinery. The current political and intellectual elite has no awareness of the importance of preserving the national memory and, in consequence, strengthening its custodial institutions, in particular the Kotor Historical Archives.

Anne J. GILLILAND - Sue McKEMMISH, The Role of Participatory Archives in Furthering Human Rights, Reconciliation and Recovery (79)

The authors propose that in order to further human rights, the archives should adopt the participatory model. In this model, communities and individuals, authors, co-authors or subjects of the records, would be involved in decision making on the appraisal and description thereof and on the rules governing access to them. The building up of this model requires reshaping of the archival principles, strategies and regulations.

\section{Živana HEĐBELI, Archives and Human Rights in Croatia (89)}

During the 1990s, an impressive number NGOs were established in Croatia for the promotion and protection of human rights. The paper summarizes the objectives and the history of 18 organizations acting for humanitarian causes: denouncing violations of human rights, furthering women's rights, defence of peace, protection of the environment, conscientious objection etc. Preservation of the records of these NGOs is not secured. The author urges national authorities and the archival profession to endeavour protecting this essential component of the national memory.

Aida ŠKORO BABIĆ, Archival Records and Personality Rights (101)

In the second half of the last century, various international instruments were adopted for protecting the life, the physical and moral integrity, the rights and freedoms of individuals and on the punishment of crimes against humanity. The paper focuses on brutal violations of personality rights (including the destruction of civil registry and voter registers) during the Yugoslavian wars in the 1990 s, and the role of archival records as evidences in post-war trials through examples of International Criminal Tribunal of the former Yugoslavia.

2. *The author did not take the floor at the session.

3. ${ }^{* *}$ Because it reports on current EU negotiations, this contribution, could not be included in the volume. 
Cristina BIANCHI, The Importance of Archives for Human Rights: Daily Evidence in the HRWG Newsletter (109)

The Human Rights Working Group, created in 2003, became a standing ICA body in 2008. Its monthly Newsletter, compiled by HRWG Chair, Trudy Peterson, publishes international and national news, collected from paper and electronic newspapers on violations of human rights (discrimination, repression of minorities, child abuse etc.), on the recourse to archival records in the investigation on such cases, both historical and actual, and on events -restrictions and lifting of restrictions - connected with the access to archives. By highlighting the specific role of the archives in the defence of human rights, the Newsletter became an important part of the program of "advocacy" that ICA is developing about the archival profession.

Matthias BUCHHOLZ, The German Federal Government's Support of Independent Archives of the Civil Rights Movement in the Former GDR (121)

The Foundation for the reappraisal of the SED (Socialist Unity Party) dictatorship was established by the German Parliament in 1998. It collects, processes and preserves the written and oral sources of the opposition movements in the GDR, and fosters scholarly research in and educational use of this material. Funding is secured by the Government. The paper surveys the major projects carried out by the Foundation, such as the creation of the Archives of Suppressed Literature for the preservation of manuscripts banned from publication or utilized for convicting the authors in political trials.

Izet ŠABOTIĆ, Archival Material as Means of Fulfilling Civil and Human Rights (Experiences of the Archives of Tuzla Canton) (127)

In the democratization process of Bosnia-Herzegovina, launched 20 years ago, central and local archives play a significant role. Freedom of access to the archives is secured and regulated by the national archival legislation, the Freedom of Information Act (2001), the law on data protection (2004) and the law on secrecy (2005). In implementing this legislation, the Archives of Tuzla Canton resorts to information technologies in order to facilitate the use and to ensure the intellectual control and a better protection of the holdings. The Archives is visited by an increasing number of users.

\section{Access and legal requirements (data protection, copyright)}

Elisabeth SCHÖGGL-ERNST, Access to Archives: is a Restricted Access to Archival Material Still Contemporaneous? (141)

In Austria, archival legislation entered a period of renewal both at the federal and the state levels. Secrecy is banned by the Constitution from all fields except security and the defence of public interest. The introduction of open government requires revision of various legal rules e.g. on access to information of common interest as well as of the civil service law. The amended EU directive granting wider access to Public Sector Information for private and economic use covers also Archives, Libraries and Museums and thus will impose the revision of the Archives Act.

Yolanda CAGIGAS OCEJO, The Personal Archives of the Spanish Democratic Transition Presidents and Ministers (November 1975/October 1982) (149)

The death of Franco opened in Spain the democratic transition period, which ended with the parliamentary elections of December 1982. So far, research on the transition concentrated on the records of ministries and political parties. Important additional information is contained in the private papers of the Presidents of the Government and Ministers in office during the period. The paper identifies 15 personal archives out of 68, donated to or deposited with Foundations and Universities.

Svetlana USPRCOVA, Access to the archive material and its protection in the State Archives of the Republic of Macedonia (163)

The paper surveys the legal and regulatory texts governing access to public and private archives in the Republic of Macedonia. The provisions set forth in these instruments (Freedom of Information Act, Law on data protection etc.) are consolidated in the Law on Archives of 2012. The general closu- 
re period of public archives is of 20 years; longer periods are applied to records relating to national security, containing geological information, personal data etc. Access to deteriorated and fragile documents may be restricted. Implementation of the access rules is managed by the Information Service of the State Archives.

James LOWRY - Elizabeth SHEPHERD, The Open Government Partnership: Implications for National Archives (177)

In 2011, the Open Government Partnership (OGP) was established to bring governments and civil society together in the pursuit of more transparent governance. Membership of the OGP requires governments to commit to openness reforms in National Action Plans (NAP). The paper explains the importance of well managed records and therefore of proper records management for government openness. The NAP of the UK gives responsibility to the National Archives to implement the commitment on records management.

Francisco Javier AGUADO GONZÁLEZ - Inés IRURITA HERNÁNDEZ, The Political Transition to Democracy in Spain: the Importance of Personal Archives as Source for the Recent Political History (183)

Antonio Fontán Pérez (1923-2010), a prominent political personality, preceptor of the future king Juan Carlos, University professor, journalist, founder of the Liberal Party, President of the Senate and Minister during the first years of the democratic transition donated his personal archives to the University of Navarra. The paper highlights the importance of this fond for historical research. The unrestricted part of the fond (40 300 pages) is accessible on line. The classification scheme is annexed to the article.

Kaia IVASK, Public Access and Restricted Access to Archival Documents: National Archives of Estonia (195)

The database AIS, initiated in 1999, covers now the totality of the records preserved in the $\mathrm{Na}$ tional Archives. In the framework of a comprehensive digitization program, several databases have been created. The most important of them, the online portal SAAGA, contains 13 million images of records from the National Archives, from the Lutheran congregations, from the Tallinn City Archives and also collected from abroad. Access to all databases as well as submissions of requests for access to restricted material are facilitated by the Virtual Reading Room (VAU).

Tibor Csaba REISZ, The Freedom of Research and its Boundaries in the Archives in Hungary (since 1945) (201)

The paper gives a detailed account of the constantly changing and rather complex access regulations and restrictions applied in the public archives of Hungary since 1945. The current rules, based on the Archives Act of 1995, follow the international standard practice (general closure period of 30 years, longer closed periods for specific record categories). However, certain traditional restrictions (e.g. nationality and age of the user) did not disappear completely and according to the legal texts of 2010 and 2013 on civil registers, birth registers are accessible after 100, death registers after 30 years.

Bogdan-Florin POPOVICI, Private Historical Archives: Between Public Interest and Private Property in Communist Romania (219)

In the interwar period, right of ownership of archives was guaranteed. In the first phase of the Communist regime, from 1950 on, the business and family archives that belonged to the former ruling classes, as well as parts of the church archives were taken into public custody. In the second, "national communist" phase, the Archives Act of 1971 instituted the "National Archival Heritage" encompassing all historical records, and by the 1974 Law on the National Cultural Heritage all private cultural became State property. The paper presents also the arguments used for justifying the measures taken. 
Zdenka SEMLIČ RAJH, Copyright in Archives: an Instrument for the Safeguarding of Cultural Identity (229)

In spite of the existence of a large number of international and European instruments on intellectual property (listed at the end of the paper), the protection of copyright in archival (and library) practice raises various issues to be addressed case per case, e.g. designation of the owner of the copyright, conditions to be observed by the user and the status of digital documents. The proposed treaty recognizing an archival and library exception was rejected by WIPO. In order to prevent implication of the archives in litigations, the Slovenian Archives Act specifies that the user has to acquire all permissions before using copyrighted materials.

IIAS Descriptors (248) in English, Italian, Slovenian, German, French and Spanish from 2.1 Climate to 3.6 Storage containers.

Tome 2: Archives - political power - civil society: Advocacy and outreach, Education

\section{Advocacy and outreach}

\section{Iva GOBIĆ VITOLOVIĆ, Strategy for Preservation of Archival Books (13)}

The preservation of archival books (registers and documents bound in volume), often damaged and extensively used, requires time and financial means. Because of the cost involved, all concerned items cannot be treated. Action should therefore follow a preservation strategy. Individual restoration should be reserved for selected valuable and/or widely used damaged books, while the bulk of the book material will be protected by passive (optimization of storage conditions) and active (package, disinfection, deacidification) measures.

Jedert VODOPIVEC TOMAŽIČ - Jana LUDVIK, Preservation Inventory of Archival Material in Book Form (21)

Slovenian archivists undertook to include in the inventories information on the physical status of the material described. The paper presents the methodology followed by archivists and conservators in preparing the Guide to the Urbaria (land registers) preserved in the Archives of the Republic of Slovenia. For each item described, data are included on the level of preservation, damages, conditions of use in the reading room and treatment needed.

Melania ZANETTI - Alessandro GIACOMELLO - Ketti ANGELI - Alessandro PESARO, Study, Survey and Conservation of Plans from the "Tavolare" Office in Trieste (33)

The Tavolare Office of Trieste, placed under the authority of the Friuli Venezia Giulia Region, continues to handle the 40 volumes of land registers, inherited from Austria-Hungary, which still serve as property evidences. The project funded by the regional government has been carried out by the Regional School for Conservation and Restoration. 954 heavily deteriorated cadastral "variation" maps, dating from the $19^{\text {th }}$ century, contained in 9 volumes, were treated. After physical and chemical examination, maps were cleaned, old repairs removed, tears and missing areas filled. New housing was provided for the restored material. Next step is digitization.

\section{Jelka MELIK - Mateja JERAJ, Archives: Captive of the Government (51)}

The civil society has no knowledge of the activities and responsibilities of the archives. As to the archivists, they are still convinced that their professional mission is limited to the preservation and processing of historical archives for scholarly research. Governments share this approach and thus archives are placed under the authority of the Ministry of Culture in most EU countries. Contemporary archival thought emphasizes the role of archives in defending human rights. However, direct involvement in politics may be harmful, as experienced in Slovenia in 2006, when politicization of the debate on the Archives Act led to curtail access to archives. 
Triantafillia KOURTOUMI, Focusing on Evidence not Information: the Grand Convergence between Archives and Policymaking in the Knowledge Society (59)

Policymakers need to use the knowledge created and preserved in the archives so as to extend their personal memory, because awareness of the past is crucial in the avoidance of past mistakes. Archivists have to provide evidence usable by policymakers to respond to complex and urgent problems. Convergence and cooperation between policymakers and archivists are essential to secure a political practice based on evidence, as well as to achieve transparency in public life and to protect human right. The author urges that debate be pursued in order to fill the still existing gaps.

Elena ALEKSEEVA, Legal Foundations of Archival Activities in the Russian Federation $(71)^{2^{*}}$

Since 1992, an impressive number of legal and regulatory texts were enacted relating to the archival field. The most important one is the Federal Law of October 22, 2004 On the Archives of the Russian Federation. The law maintains the concept, inherited from the soviet legislation, of the Archival Fond encompassing all archives, irrespective of ownership (state, municipal and private) existing on the territory of the Russian Federation. It regulates the production of public records and their organisation at all levels of government, the access by users and also the rights of the owners of private archives.

Jovan P. POPOVIĆ, The Definition, Importance, Development, Place and Role of Advocacy in Society and the State, with Special Reference to Culture and Archival Activities (79)

Advocacy is the legal service providing expert advice within the framework of the judicial system. The exercise of the profession, regulated by law, is governed by the moral principles of humanism. The paper recapitulates the evolvement of advocacy in the six former Yugoslavian Republics. Advocacy is often needed by archives, especially in cases of copyright contest, to protect the institution, the employees or the users whose dignity and personality were outraged.

Anna KOSOVA, The Archives of the Crimea 2014: Protection, Preservation and Support.

The paper was prepared before the peninsula was attached to Russia. It describes the program developed in 2013 for the safekeeping of the documentary heritage preserved in the State Archives, 11 municipal archives and the government departments of the Autonomous Republic of Crimea (more than 7000 fonds). It surveys also the professional, cultural and scholarly events, organized by the Crimean Archives in the first months of 2014.

\section{Education}

Grazia TATÒ, Archival Training: an Obstacle Course? (103)

In our time, archival education should cope with a series of complicating factors linked with the evolvement of the archival science, the precedence of research in contemporary history, the growth of the documentary masses, the technological progress and the diversity of records. The biennial program of the Schools of Archival Science Palaeography and Diplomatics, while offering to the students direct contact with documents, is imbalanced in favour of medievalist research. The degree course in Cultural Heritage of the Faculty of Humanities of the University is disconnected from the archival reality. In Trieste, School and Faculty cooperate and IIAS conducts a successful training activity.

Andrei RYBAKOU, Training and Educating Professional Archivists and Records Managers in Belarus (109)

In Belarus, until 1991, attempts to organize archival education failed, only some seminars took place in Minsk, Grodno and Gomel in the 1980s. The Belarus State University (BSU) opened its Section of Archival Science in 1992; teaching of records management started in 2001. So far 581 historian-archivists and 590 records managers were trained in cooperation with the two Research Centres of the State Archives (BelNIIDAD and BelNITsED) and 13 MA degrees were awarded. The planned post-graduate training is not up to expectation. Because better wages are offered by business corporations, professionals trained at BSU leave the public archives. 
Bilkis BEGUM - Mamun MOSTOFA - Muhammad MEZBAH-UL-ISLAM, Developing a New Academic Discipline of Archives and Records Management (ARM) in Bangladesh (119) ${ }^{2 *}$

Departments of History and of Information Science of several Universities offer archival education programs. While since 2010, the professional association (BARMS) and the regions organise courses and workshops, the introduction of regular ARM education encounter a number of difficulties. Government, civil service and the public at large show no interest for the preservation of records, the archives lack both financial and human resources. The future of ARM, the preservation and processing of paper and digital records in Bangladesh depend upon the cooperation of all concerned agencies, associations and schools.

\section{Christian KRUSE, Archival Education in Germany in 2014 (129)}

The Bavarian Archives School, operated by the Main State Archives was founded in 1821. The Marburg Archives School, founded in 1949, serves all Länder except Bavaria. Its Advisory Council is composed of the chief archivists of the Länder, the representatives of the city archives, the church archives and the professional associations. Archival education is offered at intermediate and high levels in both schools, professional position is guaranteed to all graduates. The Department of Information Science of Potsdam University offers archival training qt BA and MA levels. Students have to seek jobs after the diploma. With these three training centres and their different focuses, Germany offers a broad range of archival training.

\section{Magdalena MAROSZ, Archival Education (141)}

Poland adhered to the Bologna Process in 1999; a dozen on universities offer archival education at BA and MA levels. The paper presents the archival curricula of four universities: Torun (Copernic U.) Poznan (Mickiewicz U.), Krakow (Pedagogic U.) and Krakow (Pontifical U.). In 2010, the Board of the Association of Polish Archivists adopted a Model of Professional competence of archivists and records managers specifying the knowledge and skill graduates of both levels should possess for processing records created since 1900. It is becoming more and more visible that Polish universities are departing from the training of archivists as historians with archival speciality, towards the education of archivists and specialists in documentation management.

Marie RYANTOVÁ - Michal WANNER, Between Tradition and Innovation: the State, Problems and Prospects of the Teaching of Archival Science in the Czech Republic (149)

The teaching of auxiliary sciences began in the Czech lands in 1784. After 1854, archivists were trained in Vienna. The State Archives School of Prague, founded in 1919, operated until 1949. From then on, archival education, linked to historical studies, has been taken care of by Universities. Currently 7 Universities offer archival courses, Prague and Hradec Králové at post-graduate level also. Over the last 20 years, the archival field has been transformed. Taking into account the political, legal and technical changes, the author outlines the ideal content of the education of archivists in our time.

\section{Mikhail V. LARIN, Modern Tendencies of Archival Education in Russia (159)}

Education of professional archivists began in the USSR in 1930. The Historico-Archival Institute of Moscow (MGIAI) trained 500 graduates per year. In 1991, it was integrated in the structure of the Russian State University for the Humanities. A new five years curriculum was introduced in 2000. With Russia joining the Bologna Process in 2003, a two level system was developed. The educational program of the Institute offers specialized training profiles for State and Municipal Archives, Military Archives, Scientific-technical and Audio-visual archives.

Jozef HANUS - Katarína VIZÁROVÁ - Milena REHÁKOVÁ - Emília HANUSOVÁ, Training and Education: the Key Role in Heritage Preservation of Archives, Libraries and Other Cultural Institutions (165)

Preservation is the basic task of the institutions and services in charge of the cultural heritage. Education of conservators and restorators, a key element for responding to this task, requires an interdisciplinary approach involving experts in a wide range of scientific and technical disciplines. The new 
study program Heritage Materials Conservation of the Faculty of Chemical and Food Technology of the Technical University of Bratislava, prepares chemical engineers specialized in the theory and practice of the protection and rehabilitation of cultural goods. The paper presents in detail the study program.

Azem KOŽAR, Contribution of the Project „Archival Practice“ Towards Education of Archivists in Bosnia and Herzegovina and Surrounding Countries (175)

For lack of regular archival education, Bosnia-Herzegovina benefited during two decades from the courses organized by the District Archives of Maribor. The situation changed in 1998, when the Archives and the Association of archivists of Tuzla Canton launched the Archival Practice project. Until 2013, 16 international conferences were held and 16 issues of the journal Arhivska Praksa, containing the proceedings of these conferences (682 contributions by professionals from 17 countries) were issued.

Francis GARABA, From Obscurity to Frontline: Striving for Transformation for Archives and the Archival Profession from an Advocacy Perspective for the Pietermaritzburg Cluster of Theological Libraries (PCTL) in South Africa (185) ${ }^{2 *}$

PCTL, established in 1990) is an association grouping the libraries of seven theological educational institutions. An investigation through questionnaires and interviews was carried out in 2011, aiming at the improvement of the archival profile of the cluster, in particular the preservation of and the access conditions to the archival holdings of these libraries. A major advocacy effort has been undertaken through various outreach activities, e.g. Open Days, exhibitions, oral history programs, publications and lectures. Plans have been developed for promoting the visibility of the religious archives.

Iulia CHEŞCĂ, Professional Training in Archives Studies in Romania: Current Status and Development Perspectives (195)

In the introduction, the author gives a summary description of the standards and rule adopted by the EU on higher and vocational education. In Romania, the alignment process to these rules has not yet been completed. The Archives Act of 1996 entrusted the training of undergraduate and graduate archivists to the National Archives School reorganized in 1991 and to the Faculty of Archivistics created in 1992 within the Police Academy. The monopoly of these institutions was suppressed in 2013. Archival associations are now authorized to create professional training centres.

Miroslav NOVAK, Archival Studies and Records Management: Some Experiences with Distance and Traditional Learning (203)

Exercising a number of professions requires the capability of handling the records produced and received. The paper presents the distance learning experience of three educational institutions based in Maribor (Faculty, Wood Industry College and Alma Mater Europea) in the field of archival and records management studies and the combination of distance learning with traditional lectures. The Moodle platform is used by two, the Blackboard platform by one institution. The content of the three courses is described.

Đoan Thi HOA, The Current Situation of Pre-Service Training of Human Resource for Archives in Vietnam $(215)^{2 *}$

Archives started to attract proper attention only since 1975, when peace was restored and the country unified. Vietnam has a dual archive system: the Communist Party's Archives and the State Archives. The State system comprises 4 National Archives Centres located in Hanoi and Ho Chi Minh City and a network of provincial and local archives. Professional education programs are delivered at college, bachelor, master and PHD levels by the University of Home Affairs (Hanoi) and the University of Social Sciences and Humanities (Hanoi and Ho Chi Minh City). Reshaping of the training curricula is underway so as to be adjusted to the progress of e-technologies in the production of records by government agencies. 
Charles KECSKEMÉTI: Summary of the Papers Presented at the 2014 Conference of IIAS and Published in "Atlanti" 2014, 31-39

\section{Miscellany}

Ludvik TOPLAK - Peter Pavel KLASINC - Zdenka SEMLIČ-RAJH, Archival Education: the Case of the Republic of Slovenia (225)

Alma Mater Europea, a private international and European University, was established in 2010. Its Maribor Centre (AMEU-ECM) opened in 2011. The Centre has 14 study programs at Bologna 1st, 2nd and 3rd degrees. The Archival Studies and Records Management program at Bologna 2nd degree covers 4 semesters. The article presents the outline and the objectives of the eight compulsory and the eleven optional courses offered in the program.

Book review by Jovan P. Popović (235): Mile Bakic, Ph.D., Evaluation of documentary material, State Archives of Montenegro, Cetinje and Official Gazette of Montenegro, Podgorica; Cetinje 2014.

IIAS Descriptors (248) in English, Italian, Slovenian, German, French and Spanish from 2.1 Climate to 3.6 Storage containers. 